\title{
The Causality between Government Revenue and Government Expenditure in Iran
}

\author{
Yousef Elyasi ${ }^{1}$, Mohammad Rahimi ${ }^{2}$
}

\begin{abstract}
The causal relationship between government revenue and government expenditure is an important subject in public economics especially to the control of budget deficit. The purpose of this study is to investigate the relationship between government revenue and government expenditure in Iran by applying the bounds testing approach to cointegration. The results of the causality test show that there is a bidirectional causal relationship between government expenditure and revenues in both long run and short run. Therefore, the results of this paper are consistent with fiscal synchronization hypothesis. The policy implication of results suggests that because of existing interdependence relation between government expenditure and revenue, the government makes its expenditures and revenues decision simultaneously. Under this hypothesis, the fiscal authorities of Iran should try to increase revenues and decrease expenditure simultaneously to control the budget deficits.
\end{abstract}

Keywords: Government revenue/expenditure, Bounds testing approach, Granger Causality, ARDL

JEL classification: C22, H10, H50

\section{Introduction}

The subject of causal relation between government revenue and expenditure has important implications for the political economy of fiscal policies in the field of public finance. Furthermore, budget deficits have been widely discussed in the literature of public finance. Understanding the behaviour of budget deficits for all economies has been a continuing to develop research agenda and it is important from a policy point of view, especially for a country like Iran, which is suffering from persistent budget deficits. In addition, this discussion is vital, since it corroborates the size of government and the

\footnotetext{
${ }^{1}$ Young Researchers Club, Mahabad Branch, Islamic Azad University, Mahabad, Iran, e-mail: yousef.elyasi@gmail.com

${ }^{2}$ Faculty of Economics and Social Science, Bu-Ali Sina University, Hamedan, Iran, e-mail: m.rahimi@basu.ac.ir
} 
structure of taxation and expenditure themselves. In which, the size of government in Iran is important issue in a few years.

Direction of causal relationship between revenue and expenditure and its implication in order to budget deficit has not been empirically resolved. Four alternative hypotheses have been used to describe the relationship between these variables in the budgetary process: (I) the tax-and-spend hypothesis, (II) the spend-and-tax hypothesis, (III) the fiscal synchronization hypothesis, and (IV) the fiscal neutrality hypothesis or institutional separation hypothesis. Over the last four decades, different studies have focused on different countries, time periods, proxy variables and different econometric methodologies to investigate the relationship between government revenues and expenditures. The empirical outcomes of these studies have been varied and sometimes found to be conflicting results. The results seem to be different on the direction of causality. The policy implications of these relationships can be significant depending upon what kind of causal relationship exists between variables.

The aim of this paper is to investigate the relationship between government revenue and expenditure in the Iranian economy. This paper tests whether government revenue causes government expenditure or whether the causality runs from government expenditure to government revenue, and if there is bidirectional causality. In investigating the government revenue and expenditure nexus, this study differs from existing studies because this study uses real per capita variables including real per capita government expenditure/ revenue and real per capita GDP.

The structure of the paper proceeds as follows: In the next section, the overview of the theoretical and empirical literature for analyzing the government revenue and government expenditure relationship is explained. The data and methodologies are explained in section 3. In section 4, the empirical results are discussed. In the final section concluding remarks and some policy implications are provided.

\section{Literature Review}

In this section, first theoretical literature is reviewed; thereafter the selected empirical studies in developed and developing countries have been presented. From point of view of theoretical studies, there are essentially four schools of thought on the direction of causation between government expenditure and revenue or variables in the budgetary process.

The first school known as tax -and- spend school, proposed by Friedman (1978) and Buchanan and Wagner (1978). Friedman (1978) argues that there is a positive causal relationship between government revenue and expenditure. While, Buchanan and Wagner (1978) stated that the causal relationship is negative. According to Friedman, increasing taxes will simply lead to more spending. Therefore, decreasing taxes is the appropriate remedy to budget deficits (Keho, 2010; Moalusi, 2004). On the contrary, Buchanan and Wagner (1978) propose an increase in taxes revenue as remedy for deficit budgets. Their point of view is that with a decline in taxes the public will perceive that the cost of government programs has fallen. 
The second school known as spend-and-tax school has been proposed by Peacock and Wiseman (1961; 1979). This school advocated that expenditure cause revenue, suggesting that first governments spend and then increase tax revenues as necessary to finance expenditures. The spend-and-tax hypothesis is valid when spending hikes created by some special events such as critical situations, that governments necessitate increasing taxes. As higher spending now will, lead to higher tax later, this hypothesis suggests that spending decreases are the desired solution to reducing budget deficits.

As the third school, fiscal synchronization hypothesis argues that governments may concurrently change expenditure and taxes, (Meltzer and Richard, 1981; Musgrave, 1966). This implies bidirectional causality between government expenditure and revenue. In addition, governments take decisions about revenues and expenditures simultaneously.

A fourth hypothesis introduced by Baghestani and McNown (1994) relates to the institutional separation of the expenditure and taxation decisions government. This perspective suggests that revenues and expenditures are independent of one another. This school is known fiscal neutrality school or institutional separation hypothesis.

The causality relationship between government revenue and government expenditure has important for policy implications, as explained earlier. Hence, there are numerous studies dealing with the causal relation between the government revenue and expenditure around the world. We provide lists of the empirical literature on the causality between government revenue and expenditure by authors, periods, countries, methodologies and empirical results in Table 1 and 2.

As it can be seen from the brief review of the findings, the evidence on the direction of causality is mixed. These variety results arise due to the different data set, alternative econometric methodologies and different countries' characteristics. Despite the fact that the relationship between government revenue and government expenditure is important to evaluate how to address fiscal imbalances, empirical research on this issue in Iran is scarce as there has been no published research in the case of Iran, which authors are aware. Nevertheless, the acceptance of any hypothesis depends on its credible explanation of the economic existence across countries with different economic structures, structural of governments and political systems.

In the case of Iran, government expenditure is financed mostly through oil exports revenues that accounted for about $60 \%$ of total government revenues in past four decades (CBI, 2010). In this study, our goal is to examine the relationship and causality between government expenditure and government revenue for Iran. Testing the empirical relationship between government revenues and expenditures is a substantial step in understanding the future path of the budget deficit. To pursuing this aim, we use the bounds testing approach to cointegration advocated by Pesaran et al. (2001) or existence of a long-run relationship among these variables and error correction models to causality tests. However GDP per capita include in the model is a control variable. Chang and Chiang (2009) argue that this approach allows us to distinguish between the direct causality relation between revenues and expenditures and the indirect causality effects via GDP. This study estimated two models one with GDP per capita and one without GDP per capita. 
Table 1: Summary of empirical studies on government revenue-expenditure nexus for country-specific studies

\begin{tabular}{|c|c|c|c|}
\hline Authors & $\begin{array}{l}\text { Countries studied and } \\
\text { period }\end{array}$ & Method & Empirical Results \\
\hline $\begin{array}{l}\text { Von Furstenberg et } \\
\text { al. (1986) }\end{array}$ & $\begin{array}{l}\text { USA (Quarterly Data } \\
1954-1982)\end{array}$ & VAR & $\mathrm{GE} \rightarrow \mathrm{GR}$ \\
\hline $\begin{array}{l}\text { Anderson et al. } \\
(1986)\end{array}$ & USA (1946-1983) & VAR & $\mathrm{GE} \rightarrow \mathrm{GR}$ \\
\hline $\begin{array}{l}\text { Manage and } \\
\text { Marlow (1986) }\end{array}$ & USA (1929-1982) & VAR & $\mathrm{GR} \rightarrow \mathrm{GE}$ \\
\hline $\begin{array}{l}\text { Baghestani and } \\
\text { McNown (1994) }\end{array}$ & $\begin{array}{l}\text { USA (Quarterly Data } \\
1955-1989)\end{array}$ & $\mathrm{ECM}$ & GR --- GE \\
\hline Darrat (1998) & Turkey ( 1967-1994) & $\begin{array}{l}\text { EG and Johansen (1988) } \\
\text { Cointegration test, ECM }\end{array}$ & $\mathrm{GR} \rightarrow \mathrm{GE}$ \\
\hline $\mathrm{Li}(2001)$ & China (1950-1997) & $\mathrm{ECM}$ & $\mathrm{GR} \leftrightarrow \mathrm{GE}$ \\
\hline $\begin{array}{l}\text { AbuAI-Foul and } \\
\text { Baghestani (2004) }\end{array}$ & $\begin{array}{l}\text { Egypt (1977-1998), } \\
\text { Jordan }(1975-2001)\end{array}$ & VAR, ECM & $\begin{array}{l}\text { GR } \rightarrow \text { GE (Egypt) } \\
\text { GR } \leftrightarrow \text { GE (Jordan) }\end{array}$ \\
\hline Al-Qudair(2005) & Saudi Arabia (1964-2001) & $\begin{array}{l}\text { EG and Johansen Cointegration } \\
\text { test, ECM }\end{array}$ & $\mathrm{GR} \leftrightarrow \mathrm{GE}$ \\
\hline $\begin{array}{l}\text { Carneiro et al. } \\
(2005)\end{array}$ & $\begin{array}{l}\text { Guinea-Bissau (1981- } \\
\text { 2002) }\end{array}$ & Granger causality test and ECM & $\mathrm{GE} \rightarrow \mathrm{GR}$ \\
\hline $\begin{array}{l}\text { Nyamongo et al. } \\
(2007)\end{array}$ & $\begin{array}{l}\text { South Africa (monthly } \\
\text { data, Oct. } 1994 \text {-June } \\
\text { 2004) }\end{array}$ & $\begin{array}{l}\text { Seasonal Unit Roots, Johanson } \\
\text { Cointegration and VECM For } \\
\text { Causality }\end{array}$ & $\begin{array}{l}\mathrm{GR} \leftrightarrow \mathrm{GE} \text { in long-run } \\
\mathrm{GR}--\mathrm{GE} \text { in short-run }\end{array}$ \\
\hline $\begin{array}{l}\text { Gounder et al. } \\
(2007)\end{array}$ & Fiji Islands (1968-2003) & $\begin{array}{l}\text { Johansen test for cointegration } \\
\text { and Granger causality }\end{array}$ & $\mathrm{GR} \leftrightarrow \mathrm{GE}$ \\
\hline $\begin{array}{l}\text { Eita \& Mbazima } \\
(2008)\end{array}$ & Namibia (1977 - 2007) & $\begin{array}{l}\text { VAR, Johansen }(1988 ; 1995) \text { and } \\
\text { Granger causality test }\end{array}$ & $\mathrm{GR} \rightarrow \mathrm{GE}$ \\
\hline Wahid (2008) & Turkey $(1975-2003)$ & Granger causality (1969) & $\mathrm{GE} \rightarrow \mathrm{GR}$ \\
\hline $\begin{array}{l}\text { Chaudhuri } \\
\text { \&Sengupta } \\
(2009)\end{array}$ & $\begin{array}{l}4 \text { southern states in India } \\
(1980-2005)\end{array}$ & ECM and Granger Causality Test & $\begin{array}{l}\text { GR } \rightarrow \text { GE: Karnataka } \\
\text { GR } \leftrightarrow \text { GE: Andhra } \\
\text { Pradesh and Kerala } \\
\text { GR--- GE: Tamil Nadu }\end{array}$ \\
\hline $\begin{array}{l}\text { Aslan and Taşdemir } \\
\text { (2009) }\end{array}$ & Turkey (1950-2007) & $\begin{array}{l}\text { EG \& GH Cointegration test, } \\
\text { Granger-Causality Test }\end{array}$ & $\mathrm{GR} \leftrightarrow \mathrm{GE}$ \\
\hline
\end{tabular}

Source: Authors compilation

Notes:

1. GE $\rightarrow$ GR: means that the causality runs from government expenditure to government revenue (spend and tax hypothesis).

2. GR $\rightarrow$ GE: means that the causality runs from government revenue to government expenditure (tax and spend hypothesis).

3. GR $\leftrightarrow$ GE: means that the bidirectional causality between government revenue and government expenditure (Fiscal synchronization hypothesis).

4. GR --- GE: means that no causality exists between government revenue and government expenditure (fiscal neutrality hypothesis).

5. Abbreviations are defined as follows: $\mathrm{VAR}=$ Vector Autoregressive Model, $\mathrm{VEC}=$ Vector Error Correction Model, ARDL=Auto Regressive Distributed Lag, ECM=Error Correction Model, GDP=Real Gross Domestic Product, EG: EngleGranger cointegration test \& GH: Gregory-Hansen Cointegration test. 
The Causality between Government Revenue and Government Expenditure in Iran

Table 2: Summary of empirical studies on government revenue-expenditure nexus for multi-country studies

\begin{tabular}{|c|c|c|c|}
\hline Authors & $\begin{array}{l}\text { Countries } \\
\text { studied }\end{array}$ & Method & Empirical Results \\
\hline $\begin{array}{l}\text { Payne } \\
(1998)\end{array}$ & $\begin{array}{l}48 \text { states } \\
\text { USA (1942- } \\
1992)\end{array}$ & $\begin{array}{l}\text { EG for } \\
\text { Cointegration, } \\
\text { ECM }\end{array}$ & $\begin{array}{l}\mathrm{GR} \rightarrow \mathrm{GE}: \text { twenty-four states } \\
\mathrm{GE} \rightarrow \mathrm{GR}: \text { eight states, GR } \leftrightarrow \mathrm{GE}: \text { eleven states } \\
\text { five remain states failed the diagnostic tests for ECM }\end{array}$ \\
\hline $\begin{array}{l}\text { Cheng } \\
(1999)\end{array}$ & $\begin{array}{l}8 \text { Latin } \\
\text { American } \\
\text { countries }\end{array}$ & $\begin{array}{l}\text { Hsiao's Granger } \\
\text { Causality } \\
\text { Method }\end{array}$ & $\begin{array}{l}\text { GR } \rightarrow \text { GE: Columbia, the Dominican Republic, Honduras and Paraguay } \\
\text { GR } \leftrightarrow \text { GE: Chile, Panama, Brazil and Peru }\end{array}$ \\
\hline $\begin{array}{l}\text { Fasano } \\
\text { and Wang } \\
(2002)\end{array}$ & $\begin{array}{l}6 \mathrm{GCC} \\
\text { Countries }\end{array}$ & $\begin{array}{l}\text { Johanson } \\
\text { cointegration } \\
\text { test, ECM }\end{array}$ & $\mathrm{GR} \rightarrow \mathrm{GE}$ \\
\hline $\begin{array}{l}\text { Chang et } \\
\text { al. }(2002)\end{array}$ & $\begin{array}{l}10 \\
\text { Countries } \\
(1951 \text { to } \\
1996)\end{array}$ & $\begin{array}{l}\text { Johansen(1988), } \\
\text { Johansen and } \\
\text { Juselius (1990), } \\
\text { Granger cau- } \\
\text { sality }\end{array}$ & $\begin{array}{l}\text { GR } \rightarrow \text { GE: Japan, South Korea, Taiwan, UK, USA } \\
\text { GE } \rightarrow \text { GR: Australia and South Africa } \\
\text { GR } \leftrightarrow \text { GE: Canada, GR --- GE: New Zealand and Thailand }\end{array}$ \\
\hline $\begin{array}{l}\text { Narayan } \\
(2005)\end{array}$ & $\begin{array}{l}9 \text { Asian } \\
\text { countries }\end{array}$ & $\begin{array}{l}\text { ARDL } \\
\text { bounds testing } \\
\text { approach, } \\
\text { VECM }\end{array}$ & $\begin{array}{l}\text { GR } \rightarrow \text { GE: Indonesia (1969-1999), Singapore, Sri Lanka (1960-2000) in } \\
\text { the short-run and for Nepal (1960-1996) in both the short- and long-run } \\
\text { GE } \rightarrow \text { GR: Indonesia and Sri Lanka } \\
\text { GR --- GE: India (1960-2000), Malaysia (1960-1996), Pakistan (1960- } \\
\text { 2000), Philippines (1960-2000), Thailand (1960-2000), Singapore (1963- } \\
\text { 1995) }\end{array}$ \\
\hline $\begin{array}{l}\text { Narayan } \\
\text { and } \\
\text { Narayan } \\
(2006)\end{array}$ & $\begin{array}{l}12 \text { develop- } \\
\text { ing coun- } \\
\text { tries }\end{array}$ & $\begin{array}{l}\text { Toda and } \\
\text { Yamamoto } \\
(1995) \text { causality } \\
\text { test }\end{array}$ & $\begin{array}{l}\text { GR } \rightarrow \text { GE: Chile (1973-1996), El Salvador (1954-1996), Mauritius (1966- } \\
\text { 2000), Paraguay (1958-1993) and Venezuela (1950-1996) } \\
\text { GR } \leftrightarrow \text { GE: Haiti (1967-1997) } \\
\text { GR --- GE: Ecuador (1950-1996), Guatemala (1958-1996), Guyana (1961- } \\
\text { 1996), Peru (1970-2000), South Africa (1960-2000) and Uruguay (1969-1996) }\end{array}$ \\
\hline $\begin{array}{l}\text { Wolde- } \\
\text { Rufael } \\
(2008)\end{array}$ & $\begin{array}{l}13 \text { African } \\
\text { countries }\end{array}$ & $\begin{array}{l}\text { Toda and } \\
\text { Yamamoto } \\
(1995) \text { causality } \\
\text { test }\end{array}$ & $\begin{array}{l}\text { GR } \rightarrow \text { GE: Ethiopia (1964-2003), Ghana (1965-1998), Kenya (1970- } \\
\text { 2004), Nigeria (1969-2003), Mali (1976-2003) and Zambia (1964-1999) } \\
\text { GE } \rightarrow \text { GR: Burkina Faso (1973-2003) } \\
\text { GR } \leftrightarrow \text { GE: Mauritius (1966-2003), Swaziland (1971-2003) and Zimbabwe } \\
(1976-1997) \\
\text { GR--- GE: Botswana (1971-2003), Burundi (1967-2003) \& } \\
\text { Rwanda(1968-2002) }\end{array}$ \\
\hline $\begin{array}{l}\text { Afonso } \\
\text { and Rault } \\
(2009)\end{array}$ & $\begin{array}{l}25 \\
\text { European } \\
\text { countries } \\
(1960- \\
2006)\end{array}$ & $\begin{array}{l}\text { Bootstrap Panel } \\
\text { Analysis }\end{array}$ & $\begin{array}{l}\text { GR } \rightarrow \text { GE: Germany, Belgium, Austria, Finland, UK, and for several EU } \\
\text { New Member } \\
\text { GE } \rightarrow \text { GR: Italy, France, Spain, Greece, and Portugal }\end{array}$ \\
\hline $\begin{array}{l}\text { Chang } \\
\text { and } \\
\text { Chiang } \\
(2009)\end{array}$ & $\begin{array}{l}15 \text { OECD } \\
\text { countries } \\
(1992- \\
2006)\end{array}$ & $\begin{array}{l}\text { Panel } \\
\text { Cointegration } \\
\text { and Granger } \\
\text { Causality }\end{array}$ & $\mathrm{GR} \leftrightarrow \mathrm{GE}$ \\
\hline
\end{tabular}

Source: Authors compilation

Note: See notes in Table 1. 


\section{Data and Methodology}

\subsection{Data}

This study uses annual time series data and covers the period 1963 to 2007 . We select these period because time series data on government revenue and government expenditure are only available for this period. The data are obtained from Central Bank of Iran. Total government revenue, total government expenditure and GDP in the real and per capita form are the three variables used in the estimation. The logarithm of the real government expenditures and revenues per capita and GDP per capita are used in the empirical analysis. The transformation of the series to logarithms is intended to eliminate the problem of heteroskedasticity.

\subsection{Methodology 1}

To examine the long-run relationship between government revenue and government expenditure, we employ the bounds testing approach to cointegration, proposed by Pesaran et al. (2001). In what follows, we give a brief account of the bounds testing approach. By defining a vector of three variables, $z_{t}$ where $z_{t}=\left(G E_{t}, G R_{t}, G D P_{t}\right), G E_{t}$ is the dependent variable, $G R_{t}$ and $G D P_{t}$ are two independent variables, we can implement the bounds test in the form of a conditional error correction model (CECM) as follows:

$$
\begin{aligned}
\Delta G E_{t} & =\beta_{0}+\delta_{1} G E_{t-1}+\delta_{2} G R_{t-1}+\delta_{3} G D P_{t-1}+\sum_{j=1}^{p} \vartheta_{i} \Delta G E_{t-j}+ \\
& +\sum_{j=0}^{p} \phi_{j} \Delta G R_{t-j}+\sum_{j=0}^{p} \varphi_{j} \Delta G D P_{t-j}+\mu_{t}
\end{aligned}
$$

Here, $\Delta$ is the difference operator, GE is the logarithmic of the real government expenditures per capita, GR is the logarithmic of real government revenues per capita and GDP is the logarithmic of real gross domestic product per capita, $\delta_{1}, \delta_{2}, \delta_{3}$ are the longrun multipliers and $\beta_{0}$ is the drift term. It should be noted that Equation (1) is estimated using both variables, GR and GE, as dependent variables. Two models estimated: one without per capita real GDP and one with per capita real GDP. Here in lies one of the main assets of this technique, for it proffers exactly which is the dependent variable and which is the independent variable in a particular relationship. Lagged values of $\Delta \mathrm{GE}_{\mathrm{t}}$, current and lagged values of $\Delta \mathrm{GR}_{\mathrm{t}}$ and $\Delta \mathrm{GDP}_{\mathrm{t}}$ are used to model the short-run dynamic structure. On the selection of lag lengths, namely p, Pesaran et al. (2001: 308) observe, "there is a delicate balance between choosing $\mathrm{p}$ sufficiently large to mitigate the residual serial correlation problem and, at the same time, sufficiently small so that the conditional

1 The description here is based on Narayan (2005). 
ECM is not unduly over-parameterized, particularly in view of the limited time series data which are available".

The bounds testing procedure for the absence of any level relationship between the variables is through the exclusion of the lagged levels variables $G R_{t-1}, G E_{t-1}$ and $G D P_{t-1}$ in Equation (1). This exercise amounts to the null hypotheses $H_{0}: \delta_{1}=\delta_{2}=\delta_{3}=0$ implying no cointegration, in the first step is tested by computing a general $F$ - statistic using all the variables appearing in log levels.

The $F$-test, which has a non-standard distribution, depends upon: (a) the nonstationarity properties of the data, (b) the number of independent variables, and (c) the sample size. Pesaran and Pesaran (1997) for 500 observations and Pesaran et al. (2001) for 1000 observations report two sets of critical values for a given significance level. One set of critical values assumes that all variables included in the ARDL model are I(0), while the other is calculated on the assumption that the variables are I(1). When the calculated $F$-statistic is greater than the upper bound critical value (UCB) the null hypothesis of 'no cointegration' is rejected, and when the calculated $F$-statistic is less the lower bound critical value (LCB) the null hypothesis is accepted. However, if the computed $F$-statistics falls between the UCB and LCB, then the results are inconclusive.

The bounds procedure has several advantages over alternatives such as the Engle and Granger (1987) two-step residual-based procedure for testing the null of no cointegration and the system-based reduced rank regression approach pioneered by Johansen (1988, 1995). These advantages can be summarized as follows:

1. The bounds procedure can be applied to models consisting of variables with an order of integration less than or equal to one. This approach, hence, rules out the uncertainties present when pre-testing the order of integration. To this end, Pesaran and Pesaran (1997, p. 184) observe that "pre-testing is particularly problematic in the unit-root cointegration literature where the power of unit root tests are typically low, and there is a switch in the distribution function of the test statistics as one or more roots of the $x_{t}$ process approach unity".

2. The CECM is likely to have better statistical properties than the two-step EngleGranger method because unlike the Engle-Granger method the CECM does not push the short-run dynamics into the residual terms (Banerjee et al., 1993, 1998).

3. It can distinguish dependent and independent variables. For instance, by taking say variable $G E_{t}$ as a dependent variable and $G R_{t}$ as an independent variable if one finds that based on the bounds $F$-test there is cointegration between the variables then it implies that $G E_{t}$ is the dependent variable in this relationship.

In addition, the Granger-causality tests are examined by testing whether all the coefficients of $\Delta G E_{i t-1}$ or $\Delta G R_{i t-p}$ are statistically different from zero as a group based on a standard $F$-test and/or the coefficient of the error correction is also significant (denoting long-run causation). The $F$-tests on the differenced explanatory variables depict the shortterm causal effects, whereas the significance or otherwise of the lagged error correction term denotes whether there is a long-run relationship, (Narayan, 2005; Odhiambo, 2010). 


\section{Empirical results}

\subsection{Unit root test}

We begin our empirical analysis by testing for unit roots in the government revenue, government expenditure per capita and real GDP per capita. The bounds testing approach is based on the assumption that the variables are I(0) or I(1). Therefore, the implementation of unit root tests in the ARDL procedure might still be necessary in order to ensure that none of the variables is I(2) or beyond. To establish the integrational properties of the series, we apply the conventional Augmented Dickey and Fuller (ADF, 1979) test and Phillips-Perron (PP, 1988) test. The ADF test and PP test methodology is widely used and known; hence, we do not repeat these methodology here. The calculated $t$-statistics together with the lag length selected using the Akaike Information Criterion (AIC) and the critical values at the 5\% level of significance in ADF and PP tests have reported in Table 3. The calculated $t$-statistics for the levels of GE, GR and GDP series are greater than the critical values at the $5 \%$ level of significance. This implies that we cannot reject the unit root null hypothesis in both ADF and PP tests. However, when we convert these series into first difference and subject the series to the ADF test and PP test, the calculated $t$-statistic for all three variables is smaller than the critical values at the 5\% level. This implies that we can reject the unit root null hypothesis for three series in first difference form. As a result, all variables are integrated of order one.

Table 3: Unit root test results

\begin{tabular}{|c|c|c|c|c|c|}
\hline \multicolumn{2}{|c|}{ Test } & \multicolumn{2}{|c|}{ ADF } & \multicolumn{2}{c|}{ PP } \\
\cline { 3 - 6 } Variables & $\begin{array}{c}\text { Intercept and } \\
\text { Trend }\end{array}$ & $\begin{array}{c}\text { Intercept and } \\
\text { no Trend }\end{array}$ & $\begin{array}{c}\text { Intercept and } \\
\text { Trend }\end{array}$ & $\begin{array}{c}\text { Intercept and } \\
\text { no Trend }\end{array}$ \\
\hline \multirow{5}{*}{ Level } & \multirow{2}{*}{ GE } & $\begin{array}{c}-0.202,[1] \\
(-2.931)\end{array}$ & $\begin{array}{c}-2.478[2] \\
(-3.521)\end{array}$ & $\begin{array}{c}-0.049[4] \\
(-2.929)\end{array}$ & $\begin{array}{c}-1.753[4] \\
(-3.516)\end{array}$ \\
\cline { 2 - 6 } & \multirow{2}{*}{ GR } & $\begin{array}{c}0.182[0] \\
(-2.928)\end{array}$ & $\begin{array}{c}-2.588[3] \\
(-3.524)\end{array}$ & $\begin{array}{c}-0.015[3] \\
(-2.929)\end{array}$ & $\begin{array}{c}-1.851[4] \\
(-3.516)\end{array}$ \\
\cline { 2 - 6 } & \multirow{2}{*}{ GDP } & $\begin{array}{c}1.164[1] \\
(-2.931)\end{array}$ & $\begin{array}{c}-1.942[2] \\
(-3.521)\end{array}$ & $\begin{array}{c}1.569[4] \\
(-2.929)\end{array}$ & $\begin{array}{c}-1.655[4] \\
(-3.516)\end{array}$ \\
\hline \multirow{4}{*}{ First } & \multirow{2}{*}{$\Delta \mathrm{GE}$} & $\begin{array}{c}-4.423[0] \\
(-2.931)\end{array}$ & $\begin{array}{c}-4.365[0] \\
(-3.518)\end{array}$ & $\begin{array}{c}-4.551[3] \\
(-2.931)\end{array}$ & $\begin{array}{c}-4.497[3] \\
(-3.518)\end{array}$ \\
\cline { 2 - 6 } & \multirow{2}{*}{$\Delta \mathrm{GR}$} & $\begin{array}{c}-5.204[0] \\
(-2.931)\end{array}$ & $\begin{array}{c}-5.162[0] \\
(-3.518)\end{array}$ & $\begin{array}{c}-5.299[3] \\
(-2.931)\end{array}$ & $\begin{array}{c}-5.258[3] \\
(-3.518)\end{array}$ \\
\cline { 2 - 6 } & \multirow{2}{*}{$\Delta \mathrm{GDP}$} & $\begin{array}{c}-3.345[3] \\
(-2.937)\end{array}$ & $\begin{array}{c}-3.629[3] \\
(-3.527)\end{array}$ & $\begin{array}{c}-4.223[4] \\
(-2.931)\end{array}$ & $\begin{array}{c}-4.527[4] \\
(-3.518)\end{array}$ \\
\hline
\end{tabular}

\section{Notes:}

$\dagger$ numbers in brackets represent lag length in ADF test, which is selected using the Akaike Information criterion and these numbers denote Bandwidth in PP test by applying Newey-West using Bartlett kernel.

$\$$ Numbers in parentheses represent critical values at the 5\% level of significance. 


\subsection{Cointegration, the ARDL approach results and causality test}

At this stage, our test for cointegration is based on the bounds testing approach. To capture the effect of the Iran/Iraq war period (1980-1988) as an important structural break in Iran's economy, a dummy variable (DU80) included in the model which is equal to one if $(\mathrm{t}>1980)$ and zero otherwise.

Furthermore, since we use 45 annual observations, we choose two as the maximum lag length in the ARDL model using the AIC. The $F$-statistics together with the exact critical values are reported in Table 4 when GE and GR are dependent variables in two models. The calculated $F$-statistic when per capita real government expenditure is the dependent variable is 6.46 in model (1). Given the upper critical bound value of 6.05 at the $5 \%$ level of significance, we are able to reject the null hypothesis of 'no cointegration'. In addition, following Bannerjee et al. (1998) to determine the long-run relationship among the variables of interest, we also use the $t$-test. Based on the results in Table 4, the calculated value of the $t$-test is -10.86 , which absolute value is more than the critical value -3.28 (at $5 \%$ significance level) tabulated by Bannerjee et al. (1998), so the presence of the long-run relationship is confirmed. In addition, the $F$-statistics in model (2) shows that we cannot reject the null hypothesis of 'no cointegration'. But according to Bannerjee et al. (1998), the calculated value of the $t$-test is -10.28 , that we reject the null hypothesis.

Table 4: The Estimated Autoregressive Distributed Lag Models based on AIC; dependent variable: $G E$

\begin{tabular}{|c|c|c|c|c|c|c|}
\hline \multicolumn{4}{|c|}{$\operatorname{Model}(1)-\operatorname{ARDL}(1,0,0)$} & \multicolumn{3}{|c|}{$\operatorname{Model}(2)-\operatorname{ARDL}(1,0)$} \\
\hline \multicolumn{2}{|c|}{ Regressor } & Coefficient & T-Ratio & Regressor & Coefficient & T-Ratio \\
\hline \multicolumn{2}{|r|}{ GE(-1) } & $0.399 * * *$ & 7.211 & GE(-1) & $0.473 * * *$ & 9.223 \\
\hline \multicolumn{2}{|r|}{ GR } & $0.406^{* * *}$ & 7.366 & GR & $0.495 * * *$ & 10.587 \\
\hline \multicolumn{2}{|r|}{ GDP } & $0.168 * * *$ & 2.635 & INT & -0.068 & -1.366 \\
\hline \multicolumn{2}{|r|}{ INT } & $-0.136^{* * *}$ & -2.564 & DU80 & $0.070 * * *$ & 3.474 \\
\hline \multicolumn{2}{|r|}{ DU80 } & 0.0357 & 1.553 & & & \\
\hline \multicolumn{2}{|c|}{$\mathrm{R}^{2}=0.998$} & $\bar{R}^{2}=0.998$ & $\begin{array}{c}\mathrm{F}(4,38)=726.4 \\
{[0.00]}\end{array}$ & $\mathrm{R}^{2}=.998$ & $\bar{R}^{2}=0.998$ & $\begin{array}{c}\mathrm{F}(3,39)=839.4 \\
{[0.00]}\end{array}$ \\
\hline \multirow{2}{*}{$\mathrm{GE}(0)$} & F-stat. $=6.464$ & $\mathrm{LBC}=5.076^{\dagger}$ & $\mathrm{UCB}=6.052^{\dagger}$ & F-stat. $=3.682$ & $\mathrm{LBC}=6.689^{\dagger}$ & $\mathrm{UCB}=7.451^{\dagger}$ \\
\hline & T-test $=-10.86$ & \multicolumn{2}{|c|}{$\mathrm{CV}(0.05)=-3.57$} & T-test $=-10.288$ & \multicolumn{2}{|c|}{$\mathrm{CV}(0.05)=-3.28$} \\
\hline \multirow{2}{*}{$\mathrm{GR}(0)$} & F-stat. $=5.109$ & $\mathrm{LBC}=5.076^{\dagger}$ & $\mathrm{UCB}=6.052^{\dagger}$ & F-stat. $=15.741$ & $\mathrm{LBC}=6.689^{\dagger}$ & $\mathrm{UCB}=7.451^{\dagger}$ \\
\hline & T-test $=-4.379$ & \multicolumn{2}{|c|}{$\operatorname{CV}(0.05)=-3.57$} & T-test $=-5.609$ & \multicolumn{2}{|c|}{$\mathrm{CV}(0.05)=-3.28$} \\
\hline
\end{tabular}

\section{Notes:}

1. Critical value at level $95 \%$

2. ***, **,*: Null hypothesis rejected at $1 \%, 5 \%$ and $10 \%$ significant level, respectively.

3. CV denotes critical value of Bannerjee et al. (1998) and numbers in parentheses are a level of significant. 
Nevertheless, when per capita real government revenue is the dependent variable, the calculated $F$-statistic is only 5.11 in model (1), that it falls between the upper critical bound (UCB) and lower critical bound (LBC), and then the results are inconclusive. But, according to Bannerjee et al. (1998), the calculated value of the $t$-test is -4.38 , which is absolute value greater than the critical value -3.57 (at $5 \%$ significance level) tabulated by Bannerjee et al. (1998), so the presence of the long-run relationship is confirmed. In the model without per capita real GDP when GR as dependent variable both $F$-statistic and $t$-test confirmed the cointegration relationship. To conserve space, the details of ARDL models when GR is as dependent variable are not reported here but are available from the authors upon request.

Diagnostic tests for serial correlation, functional form, normality and heteroscedasticity of the models in part I Table 5 show that there is no evidence of autocorrelation and the models passes all of the reported diagnostic tests. We also applied autoregressive conditional heteroscedasticity test of residuals that applied for time series data and these results are reported in part II Table 5. The results indicate there is not any autoregressive conditional heteroscedasticity $(\mathrm{ARCH})$ and reject the null hypothesis that exist heteroscedasticity.

Table 5: Diagnostic tests results

\begin{tabular}{|l|l|l|l|l|}
\hline & \multicolumn{3}{|c|}{ Model $(1)$} & \multicolumn{2}{c|}{ Model (2) } \\
\hline Part I & LM Version & F Version & LM Version & $F$ Version \\
\hline A: Serial Correlation & $1.012[0.314]$ & $F(1,37)=0.892[0.351]$ & $0.132[0.717]$ & $F(1,38)=0.117[0.734]^{*}$ \\
\hline B: Functional Form & $0.108[0.742]$ & $F(1,37)=0.094[0.761]$ & $1.601[0.206]$ & $F(1,38)=1.47[0.233]$ \\
\hline C: Normality & $6.162[0.046]$ & Not applicable & $3.353[0.187]$ & Not applicable \\
\hline D:Heteroscedasticity & $0.004[0.949]$ & $F(1,41)=004[0.951]$ & $0.014[0.905]$ & $F(1,41)=.0135[0.908]$ \\
\hline $\begin{array}{l}\text { A: Lagrange multiplier test of residual serial } \\
\text { correlation }\end{array}$ & C: Based on a test of skewness and kurtosis of residuals \\
\hline $\begin{array}{l}\text { B: Ramsey's RESET test using the square of } \\
\text { the fitted values }\end{array}$ & $\begin{array}{l}\text { D: Based on the regression of squared residuals on squared } \\
\text { fitted values }\end{array}$ \\
\hline Part II- Autoregressive Conditional Heteroscedasticity Test of Residuals \\
\hline $\begin{array}{l}\text { LM Statistic CHSQ (1) }=0.129[0.720] \\
\text { F(1,37)=0.111[0.741] }\end{array}$ & $\begin{array}{l}\text { LM Statistic CHSQ (1)=0.513[0.474] } \\
\text { F(1,38)=0.459[0.502] }\end{array}$ \\
\hline
\end{tabular}

Based on indicating the cointegration in previous stage, we can now estimate the long-run coefficients of the ARDL model. One of the more important issues in applying ARDL is choosing the order of the distributed lag functions. The optimal number of lags for each of the variables using the AIC are show as ARDL $(1,0,0)$ in model $(1)$ and ARDL ( 1 and 0 ) in model (2). The results on the long-run coefficients are reported in Table 6. The empirical results reveal that in the long run all of the coefficients are significant at $\% 5$ in two models except DU80 in model (1). However, empirical results indicate when 
government revenue increased by 1 percent, government expenditure increased by 0.67 , 0.94 percent in model (1) and (2), respectively. These results indicated that dummy variable (DU 80) has a positive effect on government expenditure, so the Iranian revaluation and Iran/Iraq war has a positive effect on the size of Iranian government. In addition, results indicated that when government revenue is a dependent variable, DU80 is a negative and strongly significant effected on Iranian government revenue.

Table 6: Estimated long run coefficients using the ARDL approach- Dependent variable: $\mathbf{G E}$

\begin{tabular}{|l|c|c|c|c|}
\hline & \multicolumn{2}{|c|}{ Model (1) } & \multicolumn{2}{c|}{ Model (2) } \\
\hline Regressor & Coefficient & T-Ratio & Coefficient & T-Ratio \\
\hline C(INTERCEPT) & $-0.226 * * *$ & -2.939 & -0.129 & -1.453 \\
\hline GR & $0.675^{* * *}$ & 7.474 & $0.939 * * *$ & 55.884 \\
\hline GDP & $0.280 * * *$ & 2.921 & - & - \\
\hline DU80 & 0.059 & 1.552 & $0.133^{* * *}$ & 3.951 \\
\hline
\end{tabular}

Note: ${ }^{* * *}, * * * *$ Null hypothesis rejected at $1 \%, 5 \%$ and $10 \%$ significant level, respectively.

Table 7 reports the short-run coefficient estimates obtained from the ECM version of the ARDL model. The error correction term indicates the speed of the equilibrium restoring adjustment in the dynamic model. The ECM coefficient shows how quickly/slowly variables return to equilibrium and it should have a statistically significant coefficient with a negative sign. Bannerjee et al. (1998) holds that a highly significant error correction term is further proof of the existence of a stable long-term relationship. Table 7 shows that the expected negative sign of the ECM is highly significant. The estimated coefficients of the ECM $(-1)$ is equal to -0.53 and -0.60 in model (1) and (2) when GE is as a dependent variable; respectively, suggesting that deviation from the long-term GE path is corrected by 53 and 60 percent over the following year, thus $53 \%$ and $60 \%$ of the budgetary disequilibrium in mitigated within 1 year.

Although, the long-run relationship between the variables indicating the existence of causality between variables at least in one direction, but cannot determine direction of granger causality. As explained earlier, in this study error correction model applied for causality test. The short-run causality is supported by the $F$-statistics, which are statistically significant in the both government revenue and government expenditure equation. As we find the coefficients on lagged GR in the GE equation to be significant at the 5\% level, also while those on lagged GE in the GR equation are significant, we conclude that there is a bidirectional short run causal relationship. The coefficients on the ECTs in the GE equation and in the GR equation are significant at the $1 \%$ level. Therefore, we conclude that there is a bidirectional long-run causal relationship. 
Yousef Elyasi, Mohammad Rahimi

Table 7: Error Correction Model (ECM) results

\begin{tabular}{|c|c|c|c|c|c|c|}
\hline \multicolumn{7}{|c|}{ PART A: dependent variable: dGE } \\
\hline \multicolumn{3}{|c|}{ Model (1) } & \multicolumn{4}{|c|}{ Model (2) } \\
\hline Regressor & Coefficient & T-Ratio & Regressor & \multicolumn{2}{|c|}{ Coefficient } & T-Ratio \\
\hline dGR & $0.406^{* * *}$ & 7.366 & dGR & \multicolumn{2}{|c|}{$0.495 * * *$} & 10.587 \\
\hline dGDP & $0.168 * * *$ & 2.635 & dDU80 & \multicolumn{2}{|c|}{$0.070 * * *$} & 3.474 \\
\hline dDU80 & 0.036 & 1.553 & $\operatorname{ECM}(-1)$ & \multicolumn{2}{|c|}{$-0.527 * * *$} & -10.289 \\
\hline ECM(-1) & $-0.601 * * *$ & -10.862 & & & & \\
\hline \multicolumn{2}{|c|}{$\mathrm{R}^{2}=0.782$} & $\bar{R}^{2}=0.76$ & \multicolumn{2}{|c|}{$\mathrm{R}^{2}=0.743$} & \multicolumn{2}{|r|}{$\bar{R}^{2}=0.723$} \\
\hline \multicolumn{2}{|c|}{ DW-stat. $=2.267$} & $F(4,38)=34.168[0.00]$ & \multicolumn{2}{|c|}{ DW-stat. $=2.097$} & \multicolumn{2}{|c|}{$\mathrm{F}(3,39)=37.525[0.00]$} \\
\hline \multicolumn{7}{|c|}{ PART B: dependent variable: dGR } \\
\hline & \multicolumn{2}{|c|}{ Model (1) } & \multicolumn{4}{|c|}{ Model (2) } \\
\hline Regressor & Coefficient & T-Ratio & Regressor & \multicolumn{2}{|c|}{ Coefficient } & T-Ratio \\
\hline $\mathrm{dGE}$ & $0.507 * * *$ & 2.821 & $\mathrm{dGE}$ & \multicolumn{2}{|c|}{$1.314^{* * *}$} & 8.777 \\
\hline dGDP & $1.350 * * *$ & 5.243 & $\mathrm{dGE}(-1)$ & \multicolumn{2}{|c|}{$0.309 * *$} & 1.965 \\
\hline $\mathrm{dGDP}(-1)$ & $0.388 * *$ & 2.053 & dDU80 & \multicolumn{2}{|c|}{$-0.094 * *$} & -2.522 \\
\hline dDU80 & $-0.093 * * *$ & -3.040 & $\operatorname{ECM}(-1)$ & \multicolumn{2}{|c|}{$-0.793 * * *$} & -5.609 \\
\hline $\operatorname{ECM}(-1)$ & $-0.561 * * *$ & -4.379 & & & & \\
\hline \multicolumn{2}{|c|}{$\mathrm{R}^{2}=0.842$} & $\bar{R}^{2}=0.815$ & \multicolumn{2}{|c|}{$\mathrm{R}^{2}=0.729$} & & $\bar{R}^{2}=0.693$ \\
\hline DW-sta & 2.232 & $\begin{array}{c}\mathrm{F}(4,38)=38.279 \\
{[0.00]}\end{array}$ & DW-stat. & $=1.976$ & $\mathrm{~F}(3$ & $39)=24.944[0.00]$ \\
\hline
\end{tabular}

Note: $* * *, * * * *$ Null hypothesis rejected at $1 \%, 5 \%$ and $10 \%$ significant level, respectively.

In summarize, the results reported in Table 7 show that in the short run and long run there is bidirectional causality between government revenue and government expenditure in two models. This outcome is consistent with Musgrave (1966) and Meltzer and Richard (1981). However, the evidence of Granger causality between government expenditure and government revenue is consistent with the findings of Payne (1998), Cheng (1999) for Chile, Panama, Brazil and Peru, Li (2001), Chang et al. (2002) for Canada, AbuAI-Foul and Baghestani (2004) at the case of Jordan, Al-Qudair(2005), Gounder et al. (2007), Aslan and Taşdemir (2009), Chang and Chiang (2009). In addition, Wolde-Rufael (2008) founds a same result for Mauritius, Swaziland and Zimbabwe.

The policy implication of the results suggests that there is interdependence relation between government expenditure and revenue infers the governments make its expenditures and revenues decision simultaneously. Under this hypothesis, the fiscal authorities of Iran should try to increase revenues and decrease expenditure simultaneously in order to control the budget deficits.

Finally, the cumulative sum (CUSUM) and the cumulative sum of squares (CUSUMQ) applied to analyzing the stability of the long-run coefficients together with the short-run dynamics, (see, Figure 1 and 2). The results clearly indicated the absence of any 
instability of the coefficients during the investigation period because the plots of the two statistics are confined within the $5 \%$ critical bounds pertaining to the parameter stability.

\section{Figure 1: Plots of CUSUM and CUSUMQ statistics of Model(1); dependent variable GE (GDP included)}

Plot of Cumulative Sum of Recursive Residuals

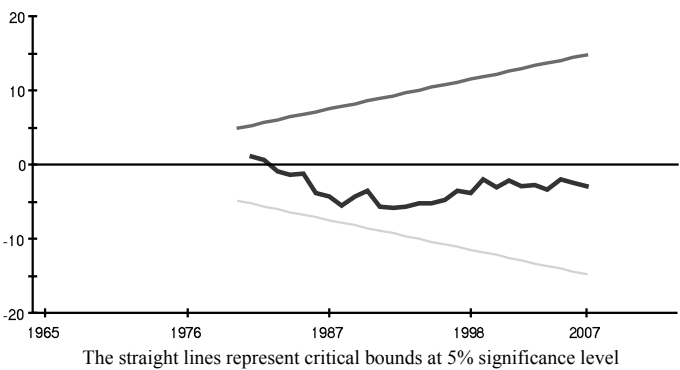

Plot of Cumulative Sum of Squares of Recursive Residuals

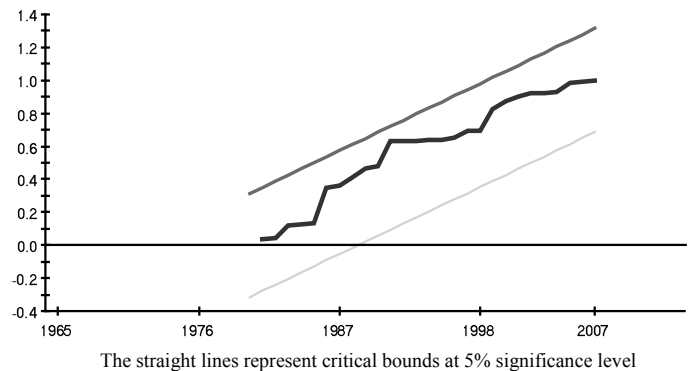

Figure 2: Plots of CUSUM and CUSUMQ statistics of Model(2); dependent variable GE

Plot of Cumulative Sum of Recursive Residuals

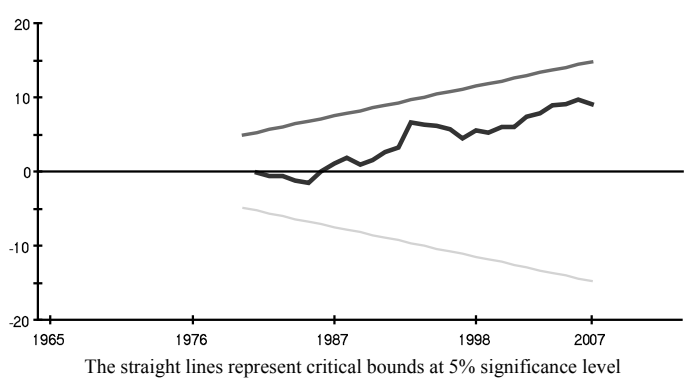

Plot of Cumulative Sum of Squares of Recursive Residuals

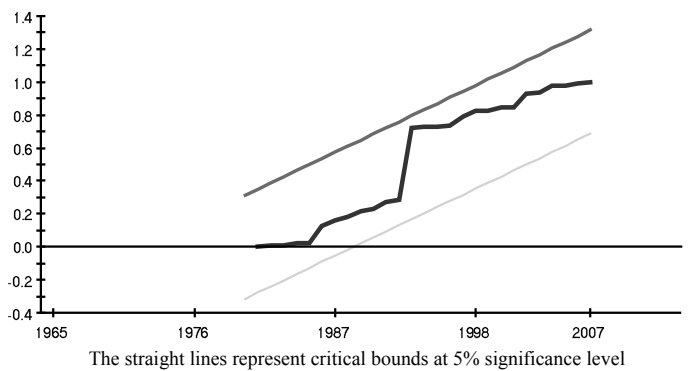

\section{Conclusion}

This study re-examined an important subject between government expenditure and revenue in the area of public economics, also the study attempts to answer one critical question. Is there a causal relationship between government expenditure and government revenue in Iran? We investigated this issue by applying the bound testing approach to cointegration, ARDL and the causality test. Analyzing data properties using the ADF and PP unit root tests indicating that the series are I(1). We find a cointegration relationship between government revenue, expenditure and GDP; all variables in real per capita form. However, applying the ECM version of the ARDL model shows that the error correction coefficient, which determines the speed of adjustment, has an expected and highly significant negative sign. The results indicated that deviation from the long-term growth 
rate in government expenditure (revenue) is corrected by approximately 53 to 60 (56 to 79) percent in the following year. We found the estimated model passes a battery of diagnostic tests and the graphical evidence (CUSUM and CUSUMQ figures) suggest that the models are stable during the sample period.

Moreover, the paper tests whether government revenue causes government expenditure or whether the causality runs from government expenditure to government revenue, and if there is bidirectional causality. The results show that there is bidirectional causality from government revenue to government expenditure. So, these result consistent with the fiscal synchronization hypothesis.

The policy implication of the results suggests that there is interdependence relation between government expenditure and revenue. The government makes its expenditures and revenues decision simultaneously. Under this scenario, the fiscal authorities of Iran should try to increase revenues and decrease expenditures simultaneously in order to control the budget deficits. That may be reason to the fact that government's decisions depends on its oil revenues that fluctuate over time which in turn affect the government expenditure and the growth of the economy. On the other hand, increasing government expenditure stimulates economic activities, which in turn increase government non-oil revenues. In addition, the bidirectional causality between government expenditure and revenues might complicate the government's efforts to control the budget deficit.

\section{Acknowledgment}

Helpful comments and suggestions by Professor Anastasios Karasavvoglou, Editor in Chief and anonymous referees of this journal on earlier draft of this paper are acknowledged. In addition, the authors gratefully acknowledge helpful suggestions by Mohammad Sadjadi from Soran University. The usual caveat applies.

\section{References}

Abuai-Foul, B. and Baghestani, H., 2004, 'The Causal Relation between Government Revenue and Spending: Evidence from Egypt and Jordan', Journal of Economics and Finance, 28, 2, pp. 260-269.

Afonso, A. and Rault, C., 2009, 'Bootstrap Panel Granger-Causality between Government Spending and Revenue in the EU', Economics Bulletin, 29, 4, pp. 2542-2548.

Al-Qudair, Khalid H., 2005, 'The Relationship between Government Expenditure and Revenues in the Kingdom of Saudi Arabia: Testing for Cointegration and Causality', Journal of King Abdul Aziz University: Islamic Economics, 19, 1, pp. 31-43.

Anderson, W., M. S. Wallace and Warner, J. T., 1986, 'Government Spending and Taxation: What Causes What?' Southern Economic Journal, 52, 3, pp. 630-639.

Aslan, M. and Taşdemir M., 2009, 'Is Fiscal Synchronization Hypothesis Relevant for Turkey? Evidence from Cointegration and Causality Tests with Endogenous Structural 
Breaks' Journal of Money, Investment and Banking; Issue 12, pp. 14-25.

Baghestani, H. and Mcnown R., 1994, 'Do Revenue Or Expenditure Respond To Budgetary Disequilibria?' Southern Economic Journal, 61, 2, pp. 311-322.

Banerjee, A. J., Dolado, J. J. and Mestre, R., 1998, 'Error Correction Mechanism Tests for Cointegration in Single Equation Framework?' Journal of Time Series Analysis, 19, 3, pp. 267-283.

Banerjee, A., Dolado, J., Galbraith, J. W. and Hendry D. F., 1993, Cointegration, Error Correction and the Econometric Analysis of Non-Stationary Data, Oxford, Oxford University Press.

Buchanan, J. M. and Wagner, R. W., 1978, 'Dialogues Concerning Fiscal Religion', Journal of Monetary Economics, 3, 4, pp. 627-636.

Central Bank of the Islamic Republic of Iran, 2010, Economic Research and Policy Department, Economic Time Series Database (http://tsd.cbi.ir/).

Chang, T. and Chiang, G., 2009, 'Revisiting the Government Revenue-Expenditure Nexus: Evidence from 15 OECD Countries Based On the Panel Data Approach', Czech Journal of Economics and Finance, 59, 2, pp. 165-172.

Carneiro, F. G., Faria, J. R. and Barry, B. S., 2005, 'Government Revenues and Expenditures in Guinea-Bissau: Causality and Cointegration', Journal of Economic Development, 30 , 1, pp. 107-117.

Chang, T., W. Liu and Caudill, S., 2002, 'Tax-and-Spend, Spend and-Tax, or Fiscal Synchronization: New Evidence for Ten Countries', Applied Economics, 34, 12, pp. 1553-61.

Chaudhuri, K. and Sengupta, B., 2009, 'Revenue-Expenditure Nexus for Southern States: Some Policy Oriented Econometric Observations', Madras School of Economics, India, Working Paper 48/2009.

Cheng, B., 1999, 'Causality between Taxes and Expenditures: Evidence from Latin American Countries', Journal of Economics and Finance, 23, 2, pp. 184-192.

Darrat, A. F., 1998, 'Tax and Spend, or Spend and Tax? An Inquiry into the Turkish Budgetary Process', Southern Economic Journal, 64, 4, pp. 840-956.

Dickey, D. A. and Fuller, W. A., 1979, 'Distributions of the Estimators for Autoregressive Time Series with a Unit Root', Journal of the American Statistical Association, 74, 366, pp. 427-431.

Eita, J. and Mbazima, D., 2008, 'The Causal Relationship between Government Revenue and Expenditure in Namibia', MPRA Paper, No. 9154.

Engle, R. F. and Granger, C. W., 1987, 'Cointegration and Error Correction Representation: Estimation and Testing', Econometrica, 55, 2, pp. 251-276.

Fasano, U. and Wang, Q., 2002, 'Testing the Relationship between Government Spending and Revenue: Evidence from GCC Countries', IMF Working Paper WP/02/201.

Friedman, M., 1978, 'The Limitations of Tax Limitations', Policy Review, pp. 7-14.

Gounder, N., Narayan, P. and Prasad, A., 2007, 'an Empirical Investigation of the Relationship between Government Revenue and Expenditure: The Case of the Fiji Islands', International Journal of Social Economics, 34, 3, pp. 147-158. 
Granger, C. W., 1988, 'Some Recent Developments in A Concept of Causality', Journal of Econometrics, 39, 1-2, pp. 199-211.

Johansen, S., 1988, 'Statistical Analysis of Cointegration Vectors', Journal of Economic Dynamics and Control, 12, 2, pp. 213-254.

Johansen, S., 1995, Likelihood Based Inference in Cointegrated Vector Autoregressive Models, Oxford: Oxford University Press.

Keho, Y., 2010, 'Budget Balance through Revenue or Spending Adjustments? An Econometric Analysis of the Ivorian Budgetary Process, 1960- 2005', Journal of Economics and International Finance, 2, 1, pp. 001-011.

Li, X., 2001, 'Government Revenue, Government Expenditure and Temporal Causality: Evidence from China' Applied Economics, 33, 4, pp. 485-497.

Manage, N. and Marlow, M., 1986, 'The Causal Relationship between Federal Expenditure and Receipts', Southern Economic Journal, 52, 3, pp. 617-629.

Meltzer, A. H., and Richard, S. F., 1981, 'A Rational Theory of the Size of the Government', Journal of Political Economy, 89, 5, pp. 914-927.

Moalusi, D., 2004, 'Causal Link between Government Spending and Revenue: A Case Study of Botswana', Fordham Economics Discussion Paper Series, Number dp2007-07.

Musgrave, R. A., 1966, 'Principles of Budget Determination' In A. H. Cameron \& W. Henderson (Eds.), Public Finance: Selected Readings (pp. 15-27), New York, Random House.

Narayan, P. K., 2005, 'The Government Revenue and Government Expenditure Nexus: Empirical Evidence from Nine Asian Countries', Journal of Asian Economics, 15, 6, pp. 1203-1216.

Narayan, P. K. and Narayan, S., 2006, 'Government Revenue and Government Expenditure Nexus: Evidence from Developing Countries’ Applied Economic, 38, 3, pp. 285-291.

Nyamongo, M., Esman, M. and Schoeman, N. J., 2007, 'Government Revenue and Expenditure Nexus in South Africa', South African Journal of Economic and Management Sciences, 10, 2, pp. 256-268.

Odhiambo, N., 2010, 'Energy Consumption, Prices and Economic Growth in Three SSA Countries: A Comparative Study’, Energy Policy, 38, 5, pp. 2463-2469.

Payne, J. E., 1998, 'The Tax-Spend Debate: Time Series Evidence from State Budgets', Public Choice, 95, 3-4, pp. 307-20.

Peacock, A. T. and Wiseman, J., 1961, The Growth of Public Expenditure in the United Kingdom. Princeston, NJ, Princeton University Press for the National Bureau of Economic Research.

Peacock, A. T. and Wiseman, J., 1979, 'Approaches to the Analysis of Government Expenditure Growth', Public Finance Quarterly, 7, 1, pp. 3-23.

Pesaran, M. H. and Pesaran, B., 1997, Working with Microfit 4.0: Interactive Econometric Analysis. Oxford, Oxford University Press.

Pesaran, M. H., Shin, Y. and Smith, R., 2001, 'Bounds Testing Approaches to the Analysis of Level Relationships', Journal of Applied Econometrics, 16, 3, pp. 289-326. 
Phillips, P. C.B. and Perron, P., 1988, 'Testing For a Unit Root in Time Series Regression', Biometrika, 75, 2, pp. 335-346.

Von Furstenberg, G. M., Jeffrey, G. R. and Jeong, Jin-Ho, 1986, 'Tax and Spend or Spend and Tax', Review of Economics and Statistics, 68, 2, pp. 179-188.

Wahid, A.N.M., 2008, 'An Empirical Investigation on the Nexus between Tax Revenue and Government Spending: The Case of Turkey', International Research Journal of Finance and Economics, 16, pp. 46-51.

Wolde-Rufael, Y., 2008, 'The Revenue-Expenditure Nexus: The Experience of 13 African Countries', African Development Review, 20, 2, pp. 273-283. 